\section{Actinomycosis is not Frequent in the Periapex But is a Persistent Lesion}

Lucas Senhorinho Esteves ${ }^{1}$, Águida Cristina Gomes Henriques' ${ }^{1}$, Carolina Ávila Varginha de Moraes e Silva², Maria Cristina Teixeira Cangussu', Eduardo Antônio Gonçalves Ramos ${ }^{3}$, Carlos Estrela ${ }^{4}$, Jean Nunes dos Santos ${ }^{1}$

Periapical actinomycosis caused by a gram-positive anaerobic pathogen characterizes a typical extra-radicular infection. This study determined the frequency and correlated the content of bacteria colonies with the of periapical actinomycosis size. The study comprised a total of 218 periapical lesions ( $\mathrm{PL}$ ) (cysts, granulomas or abscess). The specimens embedded in paraffin were sliced into $4-\mu \mathrm{m}$ sections and stained with hematoxylin-eosin, Gram, Periodic Acid-Schiff (PAS) and Grocott's stain. The presence of bacterial colonies composed of filamentous structures labeled with the histochemical stains were described as Actinomyces, and for each case, the bacterial colonies were counted and measured. The correlation between the number and size of bacterial colonies and the size of PL was tested using Pearson's adjusted correlation coefficient. From $218 \mathrm{PL}$, bacterial colonies were identified in 64 biopsies. Seven cases (0.3\%) fulfill the criteria for diagnosis of periapical actinomycosis. All of cases were therapy-resistant and did not showed periapical repair after 12 months of follow-up. Periapical surgery or dental extraction was performed. The correlation test indicated no correlation between the number of bacterial colonies and the lesion size $(p=0.752, r=-0.148)$. However, a larger bacterial colony size generally resulted in a larger periapical lesion $(P=0.000, r=0.657)$. The frequency of periapical actinomycosis was low, and this lesion should be included in the differential diagnosis of PL. The size of the Actinomyces colonies seemed to contribute to increase the size of the periapical lesion.

\author{
'Dentistry and Health Postgraduate \\ Program, Dental School, UFBA \\ - Universidade Federal da \\ Bahia, Salvador, BA, Brazil \\ ${ }^{2}$ Dental Practice, Private \\ Clinic, Salvador, BA, Brazil \\ ${ }^{3}$ Department of Pathology and \\ Forensic Medicine, School of \\ Medicine, UFBA - Universidade \\ Federal da Bahia, Salvador, BA, Brazil \\ ${ }^{4}$ Department of Stomatologic \\ Sciences, UFGO - Universidade \\ Federal University de Goiás, \\ Goiânia, GO, Brazil
}

Correspondence: Jean Nunes dos Santos, Avenida Araújo Pinho, 62, Canela, 40110-150 Salvador, BA, Brasil. Tel: +55 7132839019 .

e-mail: jeanunes@ufba.br

Key Words: actinomycosis; apical periodontitis; infection; root canal.

\section{Introduction}

Tooth carious exposure following bacterial invasion on the pulp constitutes the most common cause of pulp necrosis (1). A consequence of infection of the root canal system involves progressive stages of inflammation and changes of periapical bone structure, characterized by apical periodontitis (2). Apart from endodontic origin $(3,4)$, periapical lesions may be of non-endodontic origin (5).

The maintenance of root canal infection is the main cause of apical periodontitis in endodontically treated teeth. The aetiology of post-treatment disease have been associated with microbial aetiologic factors (intraradicular and extraradicular infection - bacteria, fungi) and nonmicrobial aetiologic factors (endogenous - true cysts and exogenous - foreign-body reaction) (2-4).

Actinomycosis is an infectious disease caused by gram-positive anaerobic pathogen, being that Actinomyces israelii $(6-8,10)$ is the most common isolated species in human actinomycosis. In the head and neck region, the most common form of actinomycosis is the cervicofacial form, which is often difficult to distinguish from other inflammatory lesions in this region (1-15). The occurrence of such infections in the oral cavity begins after the loss of mucosal integrity caused by local anesthesia, bone or tooth fractures, tooth extraction or eruption, periodontal disease, pulp exposure, or even endodontic treatment. The rupture of the mucosa facilitates the invasion of pathogens into the soft tissues and their proliferation due to the anaerobic conditions established $(9,16,17)$.

The root canal treatment management, a leakage of coronal sealing and a deficient root-filled canal are factors that favor the Actinomyces to invade the tooth periapex, and the lesion is therefore known as periapical actinomycosis $(2,3,7-9,18-21)$.

In new imaging exams have been emphasized as the high prevalence of apical periodontitis after root canal treatment (22), even against the better understanding of the factors involved in the persistence of periapical lesions and the contemporary root canal therapeutic techniques (21). During the establishment of a diagnostic hypothesis associated with persistent periapical lesions, usually the periapical actinomycosis has not been mentioned, especially due to the lack of data (2-4). Therefore, the objective of the present study is to determine the frequency of periapical actinomycosis in 218 periapical lesions and to correlate the content of bacteria colonies with the periapical lesion size. 


\section{Material and Methods}

The study comprised a total of 218 periapical lesions (cysts, granulomas or abscesses) microscopically identified in the laboratory of surgical pathology at the Dental School of Universidade Federal da Bahia, BA, Brazil and the Universidade Federal de Goiás, Brazil, from 2002-2014. The experimental design was based on previous study made by Hirshberg et al. (9). Clinicopathological data as gender, age, location, teeth, previous root canal treatment, symptom, clinical diagnosis, microscopic diagnosis, size of lesion and treatment were retrieved from the charts and/ or pathological reports. The study design was approved by institutional Ethics Committee.

The material was fixed in 10\% formalin, embedded in paraffin and sliced into 4- $\mu \mathrm{m}$ sections for morphological analysis. After staining with hematoxylin-eosin, gram, Periodic acid-Schiff (PAS), and Grocott's stain, all slides were reviewed by an experienced pathologist who recorded the morphological aspects of the lesions to confirm the diagnosis. The presence of bacterial colonies composed of filamentous structures aggregated to form a mass with color variations by hematoxylin-eosin stain ("sun ray effect") surrounded by inflammation and/or fibrosis and labeled with the histochemical stains were described as Actinomyces (9). For each case, the bacterial colonies were counted and measured in the larger diameters $(\mathrm{mm})$ and their mean number in each case was expressed. An analysis of the histological sections was performed using AxioVisionTM Rel 4.8.6 2009 software (Zeiss, Göttingen, Germany) coupled a Zeiss Axio Scope microscope (Carl Zeiss Microlmaging, Inc., Göttingen, Germany).

The correlation between the number and size of bacterial colonies and the size of periapical lesions was tested using Pearson's adjusted correlation coefficient. A level of significance of $5 \%$ was adopted $(p<0.05)$. The statistical analysis was performed using the Minitab program for Windows, version 14 (Minitab, Inc., USA).

\section{Results}

From a total of 218 periapical lesions, bacterial colonies were identified in 64 periapical biopsies. However, seven fulfill the criteria for periapical actinomycosis. The lesions affected women more frequently and the mean age of patients was 54.4 years. The mandible was more often affected in the anterior region. Radiographically, the lesions presented with well-defined radiolucency and were located in the periapical region; most patients had undergone prior root canal treatment (Table 1). All of cases were therapyresistant periapical lesions and did not show periapical repair after 12 months of follow-up. Thus, periapical surgery (surgical enucleation of lesion followed by apicoectomy) or dental extraction was performed.
The main clinical suspicion of these persistent secondary infections was apical periodontitis (Figs. 1A, 1B and 2A, 2B). Periapical actinomycosis was not mentioned as a differential diagnosis suspicion in any of the cases. Pain symptoms in the region involved were described for three cases. All cases were histopathologically diagnosed as radicular cysts associated with inflammation and actinomycosis infection due to the presence of bacterial colonies characteristic of actinomycosis. In all cases observed Actinomyces colonies were represented by small or large isolated masses forming rosettes, often surrounded by an acute, chronic, or mixed inflammatory infiltrate inside the cystic lumen (Figs. 1C, $1 \mathrm{D}, 1 \mathrm{E}, 1 \mathrm{G}, 1 \mathrm{H}, 2 \mathrm{C}$ and $2 \mathrm{D}$ ) varying from 1-9 colonies per case. The size ranged from $1-4 \mathrm{~cm}$. Histochemical techniques for PAS and Grocott highlighted bacterial colonies (Figs. $1 \mathrm{~F}, 2 \mathrm{E}$ and $2 \mathrm{~F}$ ). After the histopathological diagnosis of periapical actinomycosis, $1.5 \mathrm{~g}$ amoxicillin was administered daily for 10 days.

The correlation test indicated no correlation between the number of bacterial colonies and the lesion size $(p=0.752, r=-0148)$. However, a larger bacterial colony size generally resulted in a larger periapical lesion ( $p=0.000$, $r=0.657$ ).

\section{Discussion}

Periapical actinomycosis has been associated with etiological factors of persistent periapical lesions $(6-9,18-$ 21). From a total of 228 periapical inflammatory lesions biopsied in the present study, periapical actinomycosis represented $0.3 \%$ of these cases.

Studies have shown periapical actinomycosis in 1.8\% - $4.4 \%$ of the cases of periapical lesions $(8,9)$. Hirshberg et al. (9) evaluated the incidence of an accidental finding of actinomycotic colonies in periapical lesions and actinomycotic colonies were identified in 17 of 963 $(1.8 \%)$ periapical biopsy specimens. The cases of periapical actinomycosis had a favorable outcome after conservative surgical curettage with short-term antibiotic treatment.

Interestingly, none of the periapical biopsies in our study included any mention of actinomycosis infection in clinical suspicion. Therefore, the presence of this type of bacteria was a surprising finding. The presences of extra-radicular bacterial plaque or actinomycotic colonies are conditions that often maintain a periapical lesion after root canal treatment (18-21). Sunde et al. (19) analyzed the periapical microbiota of 36 teeth with refractory apical periodontitis. A variety of microorganisms, comprising facultative and anaerobic bacteria as well as yeasts, remained in refractory periapical endodontic lesions after long-term-root-canal treatment with calcium hydroxide (and systemic antibiotic treatment). Sulfur granules, containing Actinomyces species and other bacteria, were detected in 9 lesions (25\%), and 
many of the granules were calcified. Ricucci \&t Siqueira (21) reported a case of extraradicular actinomycosis that formed a continuum with the intraradicular infection and based on a critical review of the literature they stressed there is no evidence that apical actinomycosis is indeed an independent entity leading to persistent apical periodontitis lesions.

In this case series, women were more frequently affected, and most lesions were located in the mandible, especially in the anterior region. These findings are different from those reported in other studies in which men and the maxilla were more frequently affected (9). In addition, painful symptoms have been reported, $58 \%$ of the cases described here were asymptomatic. It is important to note that all biopsies were performed due to the presence of persistent alterations on radiographic images after root canal treatment and it has been reported that the Actinomyces leads to the development of asymptomatic and persistent periapical infection.

Radiographically, the lesions presented with welldefined periapical radiolucency and all lesions involved teeth that had undergone endodontic treatment. This finding is consistent with a previous report (9); however, we had difficulty analyzing the radiographic images because not all biopsies were accompanied by imaging exams. According Kukiane et al. (23), regarding periapical radiographic examinations, the average size of lesions in which Actinomyces is present is greater than that of lesions in which bacterial colonization is not present.

Histopathologically, all cases fulfilled the criteria for a radicular cyst (24), but all cases were associated with an Actinomyces infection. These colonies were present in the lumen or adjacent to the cyst, had different sizes, were isolated or sometimes overlapping, and were characterized by filamentous structures radiating from the center that were positive on PAS and Grocott staining and surrounded by an inflammatory infiltrate. These findings are similar to those of previous authors (25). It is important to state there are other means of identifying an Actinomyces infection. However, according to Hirshberg et al (9), in any case in which a non-healing and endodontically nonresolving lesion is associated with histopathological identification of actinomycosis colonies in the periapical specimen, the diagnosis of periapical actinomycosis should be applied.

This study showed that the average size of radicular

Table 1. Clinical aspects and microscopic analysis of cases of periapical actinomycosis

\begin{tabular}{|c|c|c|c|c|c|c|c|c|c|c|c|c|}
\hline Sex & $\begin{array}{l}\text { Age } \\
\text { (yrs) }\end{array}$ & $\begin{array}{l}\text { Location } \\
\text { (Arch) }\end{array}$ & Teeth & Fistula & $\begin{array}{l}\text { Previous } \\
\text { RCT }\end{array}$ & Symptom & $\begin{array}{c}\text { Clinical } \\
\text { diagnosis }\end{array}$ & $\begin{array}{c}\text { Microscopic } \\
\text { diagnosis }\end{array}$ & $\begin{array}{l}\text { Bacterial } \\
\text { colonies (n) }\end{array}$ & $\begin{array}{c}\text { Mean } \\
\text { colony } \\
\text { size }(\mathrm{mm})\end{array}$ & $\begin{array}{l}\text { Lesion } \\
\text { size } \\
(\mathrm{cm})\end{array}$ & Treatment \\
\hline F & 34 & Md & $\begin{array}{c}\text { Central } \\
\text { and lateral } \\
\text { incisors }\end{array}$ & No & Yes & Absent & $\mathrm{AP}$ & $\begin{array}{l}\text { Radicular } \\
\text { cyst }\end{array}$ & 1 & 2.30 & 2 & Apicoectomy \\
\hline M & 63 & Md & $\begin{array}{c}\text { First } \\
\text { premolar }\end{array}$ & Yes & No & Absent & $\mathrm{AP}$ & $\begin{array}{l}\text { Radicular } \\
\text { cyst }\end{array}$ & 3 & $\begin{array}{l}1.65 \\
0.72 \\
3.80\end{array}$ & 4 & Extraction \\
\hline $\mathrm{F}$ & 39 & $\mathrm{Md}$ & $\begin{array}{l}\text { Central } \\
\text { incisor }\end{array}$ & No & Yes & Absent & $\mathrm{AP}$ & $\begin{array}{l}\text { Radicular } \\
\text { cyst }\end{array}$ & 9 & $\begin{array}{l}0.10 \\
0.06 \\
0.09 \\
0.07 \\
0.11 \\
0.11 \\
0.12 \\
0.12 \\
0.19\end{array}$ & 1 & Extraction \\
\hline $\mathrm{F}$ & 53 & Md & $\begin{array}{l}\text { Central } \\
\text { and lateral } \\
\text { incisors }\end{array}$ & No & Yes & Present & $\mathrm{AP}$ & $\begin{array}{l}\text { Radicular } \\
\text { cyst }\end{array}$ & 3 & $\begin{array}{l}0.80 \\
0.20 \\
0.20\end{array}$ & 2.5 & Extraction \\
\hline $\mathrm{F}$ & 53 & $\mathrm{Mx}$ & $\begin{array}{l}\text { Second } \\
\text { premolar }\end{array}$ & Yes & Yes & Absent & $\mathrm{AP}$ & $\begin{array}{l}\text { Radicular } \\
\text { cyst }\end{array}$ & 1 & 0.20 & 0.8 & Extraction \\
\hline M & 67 & $\mathrm{Md}$ & Canine & No & Yes & Present & $\mathrm{AP}$ & $\begin{array}{l}\text { Radicular } \\
\text { cyst }\end{array}$ & 6 & $\begin{array}{c}0.40 \\
0.50 \\
0.70 \\
0.4 \\
0.60 \\
0.70\end{array}$ & 1.3 & Extraction \\
\hline F & 72 & Md & $\begin{array}{l}\text { First } \\
\text { molar }\end{array}$ & No & Yes & Present & Abscess & $\begin{array}{l}\text { Radicular } \\
\text { cyst }\end{array}$ & 1 & 0.90 & 1 & Extraction \\
\hline
\end{tabular}

F: Female; M: Male; Mandibular: Md; Maxillary: Mx; RCT: root canal treatment; AP: apical periodontitis. 

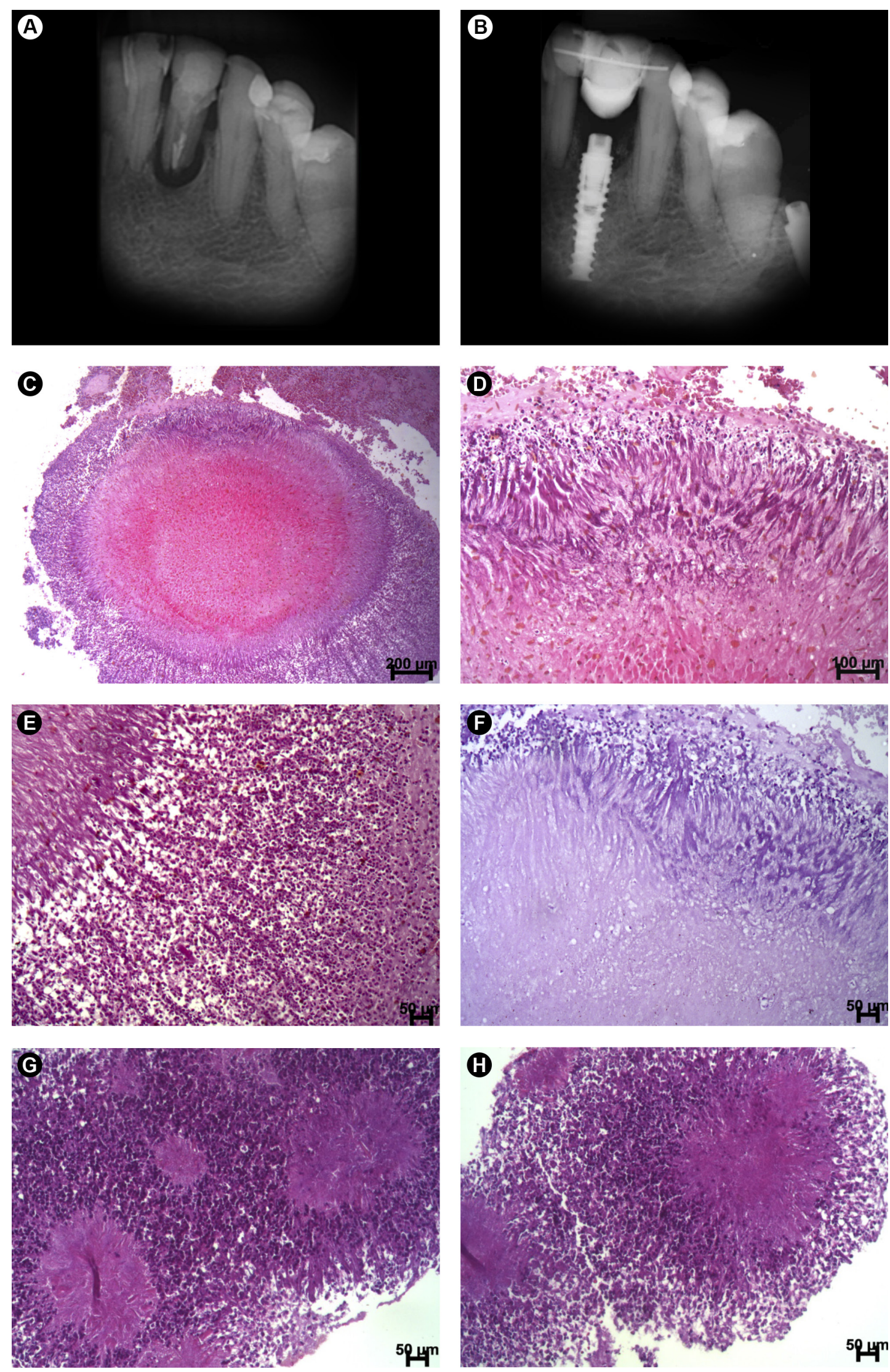

Figure 1. Case of periapical actinomycosis. A: Periapical radiograph of tooth \#32 showing apical periodontitis associated with root canal treatment failure; B: tooth extraction and implant placement; C: large bacterial colony within the cystic lumen; D: high magnification showing the peripheral edge of thick radiating clubs; E: high magnification showing the accumulation of leukocytes around the bacterial colonies; F: high magnification of Figure D showing PAS-positive colonies; G: bacterial colonies of different sizes surrounded by numerous neutrophils; H) high magnification showing a more basophilic core and peripheral radiating clubs. 
cysts with Actinomyces colonization was $1.78 \mathrm{~cm}$, which is similar to the value reported by a previous study (24) in which the average size of these cysts was nearly 2.0 $\mathrm{cm}$. When this result was compared with those previously described by Kukiane et al. (23), although that study used a method different from the one applied in the present study, the presence of Actinomyces did not appear to increase the size of the radicular cyst lesions. In addition, the number of bacterial colonies per lesion was also similar to that observed by Hirshberg et al. (9). It could be hypothesized that a larger colony size resulted in a larger radicular cyst as correlation test was significant; however, the bacterial colonies were inside the cystic lumen but a greater number of cases could clarify this matter.

In summary, root canal infections are frequently responsible for apical periodontitis, but the frequency of periapical actinomycosis was low in this study. However, periapical actinomycosis should be included in the differential diagnosis of persistent periapical lesions. In addition, other studies are needed to better understand whether the size of the Actinomyces colonies contributes to increase the size of the periapical lesion
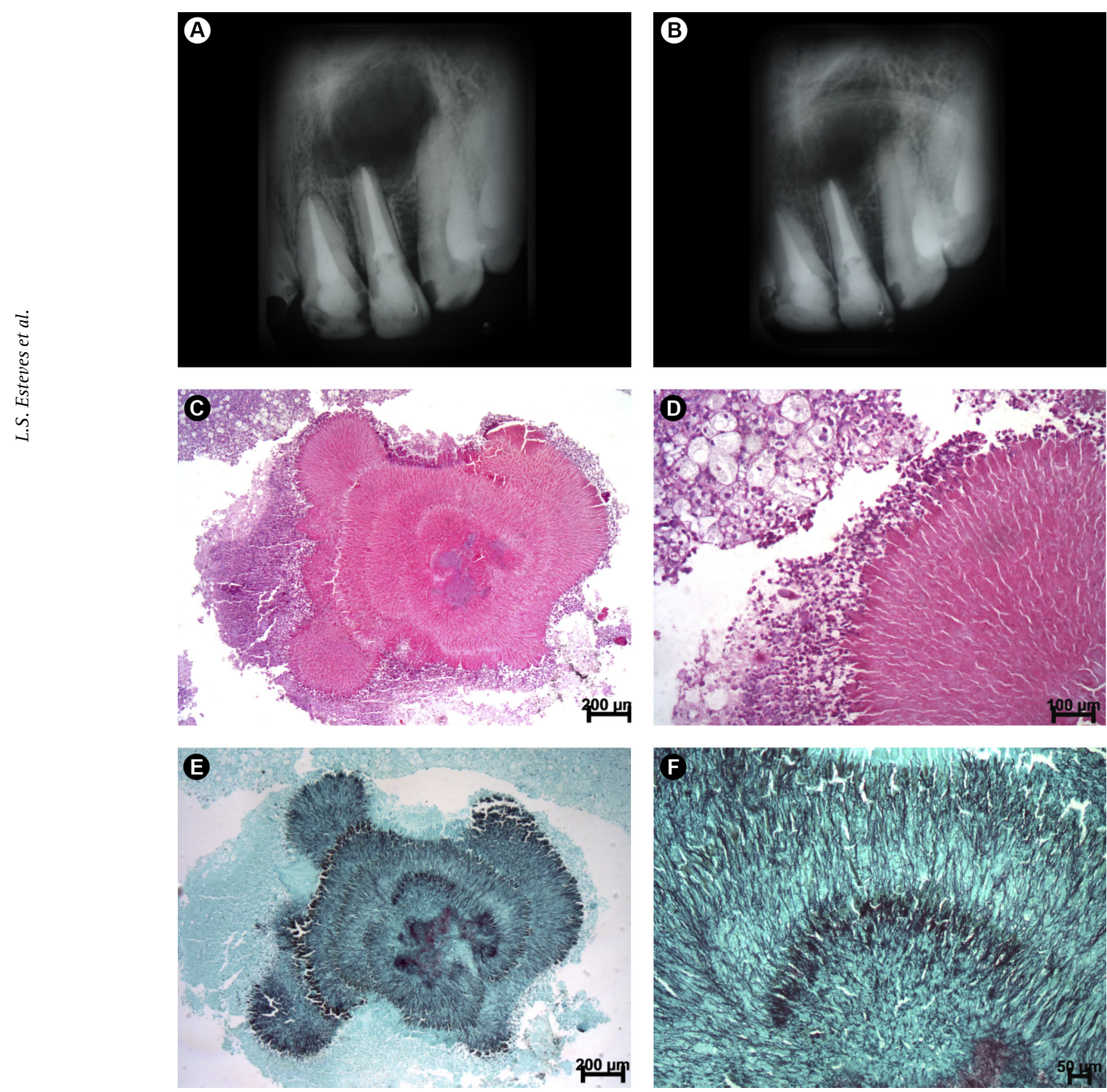

Figure 2. Case of periapical actinomycosis. A: Large well-circumscribed radiolucent image involving the periapical region of tooth \# 22; B: periapical image after apicoectomy; C: histopathologic analysis showing periapical actinomycosis (note the large bacterial colony with peripheral buddings); D: periphery with radiating actinomycetes (note the neutrophils surrounding the bacterial colony); E: Grocott silver-positive actinomycetes; F: high magnification showing thin and superimposed clubs. 


\section{Resumo}

A actinomicose periapical causada por um patógeno anaeróbio Gram positivo caracteriza uma infeç̧ão extra-radicular típica. Esse estudo determinou a frequência e correlacionou o conteúdo das colônias bacterianas com o tamanho das actinomicoses periapicais. 0 estudo compreendeu um total de 218 lesões periapicais (LPs) (cistos, granulomas ou abscessos). Os espécimes embebidos em parafina foram cortados em secções de 4- $\mu \mathrm{m}$ e corados com hematoxilina-eosina, Gram, ácido periódico de Schiff (PAS) e coloração de Grocott. A presença de colônias bacterianas compostas por estruturas filamentosas marcadas com os corantes histoquímicos foram descritas como Actinomyces, e para cada caso, as colônias bacterianas foram contadas e mensuradas. A correlação entre o número e tamanho das colônias bacterianas e o tamanho das LPs foi testado usando o coeficiente de correlação ajustado de Pearson. De 218 LPs, colônias bacterianas foram identificadas em 64 biópsias. Sete casos $(0,3 \%)$ preencheram os critérios para o diagnóstico de actinomicose periapical. Todos os casos foram resistentes à terapia e não mostraram reparo periapical após 12 meses de acompanhamento. Cirurgia periapical ou extração dental foi realizada. 0 teste de correlação indicou nenhuma correlação entre o número de colônias bacterianas e o tamanho da lesão $(p=0.752, r=-0.148)$. Entretanto, uma maior colônia bacteriana geralmente resultou em uma maior lesão periapical ( $p=0.000, r=0.657)$. A frequência de actinomicose periapical foi baixa e esta lesão deve ser incluída no diagnóstico diferencial das LPs. 0 tamanho das colônias de Actinomyces pareceu contribuir para o aumento no tamanho da lesão periapical.

\section{References}

1. Kakehashi S, Stanley HR, Fitzgerald RJ. The effects of surgical exposures of dental pulps in germ-free and conventional laboratory rats. Oral Surg Oral Med Oral Pathol 1965;20:340-9.34

2. Nair PNR. Non-microbial etiology: foreign body reaction maintaining post-treatment apical periodontitis. Endod Topics 2003;6:114-134.

3. Nair PNR, Sjögren U, Krey G, Kahnberg KE, Sundqvist G. Intraradicular bacteria and fungi in rootfilled, asymptomatic human teeth with therapy-resistant periapical lesions: a long-term light and electron microscopic follow-up study. J Endod 1990;16:580-588.

4. Nair PNR, Sjögren U, Krey G, Sundqvist G. Therapy resistant foreign body giant cell granuloma at the periapex of a root-filled human tooth. J Endod 1990;16:589-595.

5. Santos JN, Carneiro Júnior $B$, Alves Malaquias PD, Henriques AC, Cury $\mathrm{PR}$, Rebello IM. Keratocyst odontogenic tumour arising as a periapical lesion. Int Endod J 2014;47:802-809.

6. Oppenheimer S, Miller GS, Knopf K, Blechman H. Periapical actinomycosis. Oral Surg Oral Med Oral Pathol 1978;46:101-106.

7. Sundqvist $G$, Reuterving CO. Isolation of Actinomyces israelii from periapical lesion. J Endod 1980;6:602-606.

8. Nair PNR, Schroeder HE. Periapical actinomycosis. J Endod 1984;10:567-570.
9. Hirshberg A, Tsesis I, Metzger Z, Kaplan I. Periapical actinomycosis: A clinicopathologic study. Oral Surg Oral Med Oral Pathol Oral Radiol Endod 2003;95:614-620.

10. Moghimi M, Salentijn E, Debets-Ossenkop $Y$, Karagozoglu KH, Forouzanfar T. Treatment of cervicofacial Actinomycosis: a report of 19 cases and review of literature. Med Oral Patol Oral Cir Bucal 2013;18:e627-e632.

11. Acevedo F, Baudrand R, Letelier LM, Gaete P. Actinomycosis: a great pretender. Case reports of unusual presentations and a review of the literature. Int J Infect Dis 2008;12:358-362.

12. Lo Muzio L, Favia G, Lacaita M, De Lillo A, Scully C, Napoli A et al. The contribution of histopathological examination to the diagnosis of cervico-facial actinomycosis: a retrospective analysis of 68 cases. Eur J Clin Microbiol Infect Dis 2014;33:1915-1918.

13. Oostman 0, Smego RA. Cervicofacial actinomycosis: diagnosis and management. Curr Infect Dis Rep 2005;7:170-174.

14. Alamillos-Granados FJ, Dean-Ferrer A, García-López A, López-Rubio F. Actinomycotic ulcer of the oral mucosa: an unusual presentation of oral actinomycosis. Br J Oral Maxillofac Surg 2000;38:121-123.

15. Kaplan I, Anavi K, Anavi Y, Calderon S, Schwartz-Arad D, Teicher S, et al.. The clinical spectrum of Actinomyces-associated lesions of the oral mucosa and jawbones: correlations with histomorphometric analysis. Oral Surg Oral Med Oral Pathol Oral Radiol Endod 2009;108:738-746.

16. Rubin MM, Krost BS. Actinomycosis presenting as a midline palatal defect. J Oral Maxillofac Surg 1995;53:701-703.

17. Belmont MJ, Behar PM, Wax MK. Atypical presentations of actinomycosis. Head Neck 1999;21:264-268.

18. Happonen RP. Periapical actinomycosis: a follow-up study of 16 surgically treated cases. Endod Dent Traumatol 1986;2:205-209.

19. Sunde PT, Olsen I, Debelian GJ, Tronstad L. Microbiota of periapical lesions refractory to endodontic therapy. J Endod 2002;28:304-310.

20. Nair PNR. On the causes of persistent apical periodontitis: a review. Int Endod J 2006;39:249-281.

21. Ricucci D, Siqueira-Jr JF. Apical actinomycosis as a continuum of intraradicular and extraradicular infection: case report and critical review on its involvement with treatment failure. J Endod 2008;34:1124-1129.

22. Estrela C, Bueno MR, Azevedo BC, Azevedo JR, Pécora JD. A new periapical index based on cone beam computed tomography. J Endod 2008;34:1325-1331.

23. Kukiani RM, Bhattacharyya I, Nair MK. Radiographic evaluation of periapical lesions with and without biopsy-proven actinomyces: a pilot study. Quintessence Int 2011;42:301-306.

24. Santos LCS, Bôas DSV, Oliveira GQV, Ramos EAG, Gurgel CAS, Santos JN. Histopathological study of radicular cysts diagnosed in a Brazilian population. Braz Dent J 2011;22:449-454.

25. Pasupathy SP, Chakravarthy D, Chanmougananda S, Nair PP. Periapical actinomycosis. BMJ Case Reports 2012;doi:10.1136/bcr-2012-0062

Received December 8, 2016 Accepted July 5, 2017 